\title{
Development of Quality Evaluation Model of Ideological and Political Theory Course in Colleges and Universities in the New Era
}

\author{
Fei $\mathrm{Yu}^{1}$, Jia $\mathrm{Yu}^{2}$ and Hongxiang Sun ${ }^{1, *}$
}

\author{
${ }^{1}$ School of Marxism, Xi'an University of Science and Technology, Xi'an, Shaanxi 710054, China \\ ${ }^{2}$ Chemical Engineering, Guangdong Technion-Israel Institute of Technology, Shantou, Guangdong 515063, China \\ *Corresponding author. Email: shx64@xust.edu.cn
}

\begin{abstract}
The new era put forward some new requirements for the ideological and political theory courses in colleges and universities. After the clarification of the 5 first-level indicators and 18 second-level indicators of the quality evaluation index system, the contents of secondary indicator observation points were specified. The analytic hierarchy process was used to decide the weight of each indicator, a model was built to better evaluate the quality of ideological and political theory courses. The new curriculum evaluation model aims to provide a new direction to improve the quality of ideological and political course teaching experience. The model uses different index selection and index weight determination compared to the previous studies, using the analytic hierarchy process in the course evaluation system is also rare and uncommon.
\end{abstract}

Keywords: ideological and political theory course, quality, AHP, evaluation model

\section{INTRODUCTION}

At the forum of teachers of Ideological and political theory in colleges and universities, General Secretary Xi Jinping put forward higher requirements for running ideological and political courses. Teachers are expected to achieve "six requirements" and "eight unifications". According to this announcement, combining the latest research results and practical experience of education parity theory at home and abroad, a new evaluation system should be established for the specific education goal and pattern. The clarification of the evaluation indicators, observation points, should be settled first, and then finalize a reasonable evaluation index quality evaluation model under the guidance of scientific methods.

\section{BUILD UP THE QUALITY}

EVALUATION INDEX SYSTEM OF IDEOLOGICAL AND POLITICAL THEORY COURSE IN THE NEW ERA

\subsection{The Foundation of Quality Evaluation Index System and Observation Points for Ideological and Political Theory Course}

The "element and line as the basis and the eight guidelines as the body" was put forward by General Secretary Xi
Jinping, it is used as the basis for the establishment of the evaluation index system of Ideological and political theory course. We referred to the evaluation system in domestic colleges and foreign universities such as the Massachusetts Institute of Technology, considering the specialty of ideological and political theory courses in China, an evaluation system for ideological and political courses in the new era was established.

\subsection{The Scheme of the Quality Evaluation Index}

Teaching Quality of Ideological and political course, A

$\begin{array}{lllll}\text { Teaching } & \text { Students' } & \text { Teaching } & \text { Teaching } & \text { Education } \\ \text { effect,B5 } & \text { feelings,B4 } & \text { process, B3 } & \text { content, B2 } & \text { ability, B1 }\end{array}$

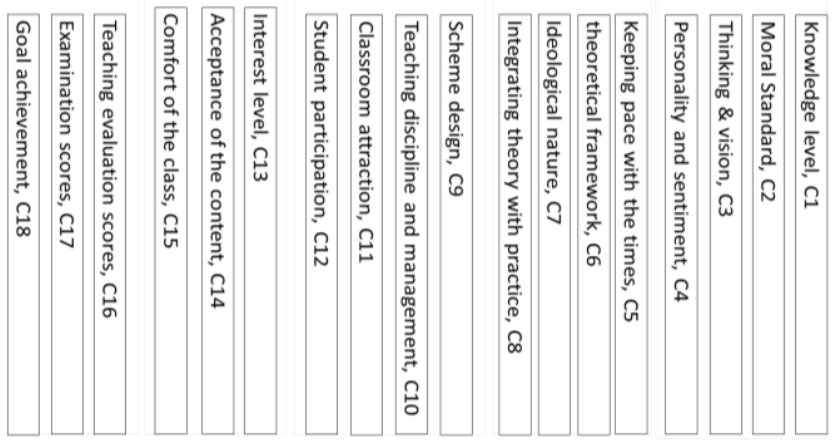

Figure 1. Strategy of the course evaluation 
An evaluation system consisting of 5 first-level indicators and 18 second-level indicators is established, see Figure 1.

\section{THE OBSERVATION POINTS OF THE EVALUATION INDEX SYSTEM}

\subsection{Observation Points under the Educational Ability}

The education ability evaluation includes four second-level indicators: knowledge level, moral standard, thinking and vision, personality, and sentiment. The observation points of knowledge level include education background and level, professional counterpart, teaching history, teaching awards\projectsipapers, and knowledge charm. The observation points of the moral standard include the title of advanced individual of teachers' morality, critical thinking, off-class interactions, social media contents, moral level, moral sentiment, moral belief, moral will, and moral behavior. The observation points of thinking and vision include being award-winning instructors of innovation competitions, challenges, social practice, dialectical thinking, strategic thinking, systematic thinking, innovative thinking, legal thinking, historical view, knowledge vision, international vision, the breadth of historical vision, etc. The observation points of personality and feelings include the teacher excellence awards at all levels, political and moral feelings and theoretical cultivation [1], care for family and country, times, world, benevolence, and preaching, etc.

\subsection{Observation Points under the Teaching Content}

The teaching content includes four second-level indicators: keeping pace with the times, theoretical framework, ideological nature, and integrating theory with practice. There are four observation points that keeping pace with the times, including the quality of teaching plan, the updating frequency of teaching materials, and the accuracy of data; clear description on theoretical points, strong logic, reasoning. Ideological observation points stand correct political position, correct direction [2], integration of core values like morality, intelligence, physique, beauty, and labor. The observation points of integrating theory with practice, close to reality and life, good at solving confusion, and so on.

\subsection{Observation Points under the Teaching Process}

The teaching process indicator includes four second-level indicators: teaching scheme design, teaching discipline and management, attraction, student participation, and so on. The observation point of the teaching scheme design includes focusing on the teaching purpose, highlighting the key and difficult points, the teaching progress meets the requirements, teaching design, appropriate selection of materials and methods, reasonable writing and material, personality, encouraging the students to think and innovate, etc. The teaching discipline and management include the class duration, attendance rate, students' attention, teachers' organization, management and control of teaching, proper clothes and makeup, elegant words and deeds, spirit, etc. The observation points of classroom attraction include the attraction of PowerPoint, content penetration, language appeal, activation, affinity, equality, and trust, etc. The observation points of students' participation include flipping classroom, discussion and debating, participation enthusiasm, and so on.

\subsection{Observation Points under the Students' Experience}

The evaluation index of students' experience includes second-level indexes, such as the interest level, acceptance of the content, comfort of the class. The observation points of interest level are students' interest stimulation, active reading of relevant materials. The observation point of content acceptance includes helping students establish correct world outlook, outlook on life and values, scientific methods of analyzing and solving problems, mastering knowledge, broadening horizons, classroom discussion over the key points, and group activities. The observation point of class comfort includes comfortable speech without pressure, free speech in-class discussion, relaxing and lively classroom atmosphere, etc.

\subsection{Observation Points under the Teaching Effect}

The evaluation index of teaching effect includes these three second-level indexes: teaching evaluation scores, examination scores, and goal achievement. The observation points for teaching evaluation scores include student evaluation [3], peer evaluation, supervisory expert evaluation, and social evaluation. The observation points of goal achievement degree are value orientation, abilitybased training, and knowledge education, progressive changes in students' emotions, attitudes, and values [4]; using Marxist theories and methods to analyze the improvement of problem-solving level; moral cultivation and improvement, system, theory and culture confidence; 
innovation and practice; honesty and truth-seeking, students' words and deeds, knowledge level, etc.

\section{MODEL DESCRIPTION}

\subsection{Determining the weight of Ideological and political course quality evaluation index based on $\mathrm{AHP}$}

Analytic Hierarchy Process (AHP) [5] is a multi-criteria decision-making method proposed by American operations research scientist Professor T. L. Saaty in the 1970s. The analytic hierarchy process is especially suitable for curriculum evaluation, which is a complex system composed of interrelated but also restrictive factors

\subsection{Developing Matrix}

To better reflect the objectivity and rationality of the index weight and avoid the subjectivity and prejudice of the developers, we have adopted a group decision-making method. The specific method is to select a total of 7 ideological and political course teaching experts, teaching supervisors, and management experts, they will compare the relative importance of factors at various levels according to the teaching objectives of Ideological and political courses, and each expert will fill in the results of their independent judgments. We will then use the average method to calculate the weight of the judgment to get a comprehensive result. When deciding weights, compare uj to ui, when equally important, the scale aij is 1 , slightly important is 3 , obviously important is 5 , very important is 7 , and absolute important is 9, and the relative importance is in the middle of the above adjacent judgments, which are $2,4,6,8$. Aji is the multiplicative inverse of aij, which means aji=1 /aij. For example, if $\mathrm{C} 2$ is obviously important than $\mathrm{C} 1$, then $\mathrm{M} 12=1 / 5, \mathrm{M} 21=5$.

\subsection{Check Consistency}

According to the comparison judgment matrix $\mathrm{A}$ of $\mathrm{n}$ elements $\mathrm{u} 1, \mathrm{u} 2, \ldots$, un to criterion $\mathrm{C}$, find their relative ranking weights $\mathrm{w} 1, \mathrm{w} 2, \ldots$, wn to criterion $\mathrm{C}$, and conduct a consistency check.

For the calculation of weights, we adopt the more mature and widely used eigen-root method, which is to find the largest eigen-root of the judgment matrix: $\mathrm{AW}=\lambda \max \mathrm{W}$, $\lambda \max$ is the largest real eigen-root of $\mathrm{A} . \mathrm{W}$ is the eigenvector of the matrix corresponding to $\lambda \max$, the normalized component of $\mathrm{W}$ is the desired weight.

When we design and construct the judgment matrix, it should ideally be consistent. However, due to the complexity of objective things and the diversity of people's understanding, decision-makers may make judgments that $\mathrm{A}$ is more important than $\mathrm{B}, \mathrm{B}$ is more important than $\mathrm{C}$, and $\mathrm{C}$ is more important than $\mathrm{C}$. It is also more important than $\mathrm{A}$ and similar judgments that violate common sense. We call that the degree of importance is not consistent, and it is questionable. Therefore, the consistency of the judgment matrix needs to be tested, namely: step 1, calculate the consistency index: C.I. $=(\lambda \max -n) /(n-1)$; step 2, use the table to find R.I., R.I. is the average value of C.I. for random matrices using the Saaty scale obtained by Forman [6] and Saaty; step 3, calculate the consistency ratio C.R, C.R. $=$ C.I. $/$ R.I.

It is only acceptable to judge a matrix as a consistent one if and only if $\mathrm{CR}<0.1$

Table 1. R.I. with Corresponding Matrix Order

\begin{tabular}{|c|c|}
\hline Order of the Matrix & R.I. \\
\hline 1 & 0 \\
\hline 2 & 0 \\
\hline 3 & 0.58 \\
\hline 4 & 0.90 \\
\hline 5 & 1.12 \\
\hline 6 & 1.25 \\
\hline
\end{tabular}

\section{WEIGHT DECIDING}

Here we give the matrix of expert $\# 1$, check the consistency, calculate the weight, then we average the weight from 7 experts and get a final weight result.

\subsection{Matrix $A B$}

For course teaching quality A, compare the importance of educating ability $\mathrm{B} 1$, teaching content $\mathrm{B} 2$, teaching process B3, student experience B4, and teaching effect B5. We asked each expert to give a rate like a matrix below, the judgment values are given and recorded as $A B$, and then their consistency will be checked.

$\lambda$ max $=5.201$, C.R. $=(5.201-5) /(5-1) / 1.12=0.045<0.1$, so

$\mathrm{AB}=\begin{array}{ccccccc}\mathrm{A} & \mathrm{B} 1 & \mathrm{~B} 2 & \mathrm{~B} 3 & \mathrm{~B} 4 & \mathrm{~B} 5 & \text { weight } \\ \mathrm{B} 1 & \mathrm{~B} 2 & 1 / 3 & 1 & 1 & 1 / 3 & 0.1187 \\ \mathrm{~B} 2 & 1 & 3 & 3 & 1 & 0.3561 \\ \mathrm{~B} 3 & \mathrm{~B} & 1 / 3 & 1 & 1 & 1 & 0.1479 \\ \mathrm{~B} 4 & 1 & 1 / 3 & 1 & 1 & 1 & 0.1479 \\ \mathrm{~B} 5 & 3 & 1 & 1 & 1 & 1 & 0.2295\end{array}$

the matrix is consistent.

We summarize weights into the table for all the 7 experts, see Table 2. We use A.W. for the short of averaged weight.

Table 2. Weight summary and average weight for AB

\begin{tabular}{|c|c|c|c|c|c|c|c|c|}
\hline & $\# 1$ & $\# 2$ & $\# 3$ & $\# 4$ & $\# 5$ & $\# 6$ & $\# 7$ & A.W. \\
\hline B1 & 0.1187 & 0.1612 & 0.0576 & 0.2426 & 0.1826 & 0.1859 & 0.1232 & 0.1531 \\
\hline B2 & 0.3561 & 0.3580 & 0.3961 & 0.1947 & 0.2613 & 0.3593 & 0.2584 & 0.3120 \\
\hline B3 & 0.1479 & 0.1487 & 0.4165 & 0.2426 & 0.1684 & 0.1492 & 0.1535 & 0.2038 \\
\hline B4 & 0.1479 & 0.1193 & 0.0605 & 0.1255 & 0.1466 & 0.1198 & 0.1912 & 0.1301 \\
\hline B5 & 0.2295 & 0.2127 & 0.0692 & 0.1947 & 0.2410 & 0.1859 & 0.2737 & 0.2010 \\
\hline
\end{tabular}




\subsection{Matrix $B_{n} C$}

For matrix B1C, the experts decided the weights under the educational ability, they compared knowledge level, moral standard, thinking and vision, personality, and sentiment by pair.

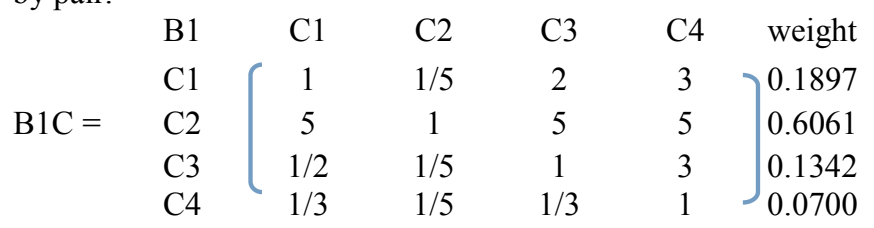

$\lambda \max =4.224$, C.R. $=(4.224-4) /(4-1) / 0.90=0.083<0.1$,so the matrix is consistent.

Table 3. Weight summary and average weight for B1C

\begin{tabular}{|c|c|c|c|c|c|c|c|c|}
\hline & $\# 1$ & $\# 2$ & $\# 3$ & $\# 4$ & $\# 5$ & $\# 6$ & $\# 7$ & A.W. \\
\hline
\end{tabular}
\begin{tabular}{|l|l|l|l|l|l|l|l|l|}
\hline C1 & 0.1897 & 0.1000 & 0.2500 & 0.2019 & 0.1824 & 0.0549 & 0.0728 & 0.1502 \\
\hline
\end{tabular} \begin{tabular}{|l|l|l|l|l|l|l|l|l|}
\hline C2 & 0.6061 & 0.3000 & 0.2500 & 0.3757 & 0.2400 & 0.0722 & 0.2013 & 0.2922 \\
\hline
\end{tabular} \begin{tabular}{|l|l|l|l|l|l|l|l|l|l|}
\hline $\mathrm{C} 3$ & 0.1342 & 0.3000 & 0.2500 & 0.1824 & 0.3757 & 0.2214 & 0.1089 & 0.2247 \\
\hline
\end{tabular} \begin{tabular}{|l|l|l|l|l|l|l|l|l|}
\hline C4 & 0.0700 & 0.3000 & 0.2500 & 0.2400 & 0.2019 & 0.6515 & 0.6169 & 0.3329 \\
\hline
\end{tabular}

For matrix $\mathrm{B} 2 \mathrm{C}$, the experts decided the sublayer weights under the teaching content, they compared keeping pace with the times, theoretical framework, ideological nature and integrating theory with practice.

$\mathrm{B} 2 \mathrm{C}=\begin{gathered}\text { B2 } \\ \text { C5 } \\ \text { C6 } \\ \text { C } \\ \text { C7 } \\ \text { C8 }\end{gathered} \quad\left[\begin{array}{ccccc}1 & \text { C6 } & \text { C7 } & \text { C8 } & \text { weight } \\ 3 & 1 / 3 & 1 / 3 & 1 / 2 & 0.1199 \\ 3 & 1 & 1 & 1 / 3 & 0.2469 \\ 2 & 1 & 3 & 1 / 3 & 0.2469 \\ & & 1 & 1 & 0.3864\end{array}\right.$

$\lambda \max =4.055$, C.R. $=0.021<0.1$, the matrix is consistent.

Table 4. Weight summary and average weight for B2C

\begin{tabular}{|c|c|c|c|c|c|c|c|l|}
\hline & $\# 1$ & $\# 2$ & $\# 3$ & $\# 4$ & $\# 5$ & $\# 6$ & $\# 7$ & A.W. \\
\hline C5 & 0.1199 & 0.3118 & 0.2453 & 0.1864 & 0.1372 & 0.0456 & 0.2538 & 0.1857 \\
\hline
\end{tabular} \begin{tabular}{|l|l|l|l|l|l|l|l|l|l|}
\hline C5 & 0.1199 & 0.3118 & 0.2453 & 0.1864 & 0.1372 & 0.0456 & 0.2538 & 0.1857 \\
\hline
\end{tabular} \begin{tabular}{|l|l|l|l|l|l|l|l|l|l|}
\hline C6 & 0.2469 & 0.1236 & 0.3229 & 0.2453 & 0.3126 & 0.0955 & 0.1364 & 0.2119 \\
\hline
\end{tabular} \begin{tabular}{|l|l|l|l|l|l|l|l|l|l|}
\hline C7 & 0.2469 & 0.1236 & 0.1864 & 0.2453 & 0.3126 & 0.2045 & 0.1232 & 0.2061 \\
\hline
\end{tabular} \begin{tabular}{|l|l|l|l|l|l|l|l|l|}
\hline C8 & 0.3864 & 0.4410 & 0.2453 & 0.3229 & 0.2376 & 0.6545 & 0.4866 & 0.3963 \\
\hline
\end{tabular}

For matrix B3C, the experts decided the sublayer weights under the teaching process, they compared teaching scheme design, teaching discipline and management, attraction, student participation in each pair.

B3C $=\begin{gathered}\text { B3 } \\ \text { C9 } \\ \text { C10 } \\ \text { C11 } \\ \text { C12 }\end{gathered}\left(\begin{array}{ccccc}1 & \text { C10 } & \text { C11 } & \text { C12 } & \text { weight } \\ 1 & 1 & 1 / 3 & 1 / 2 & 0.1479 \\ 3 & 3 & 1 / 3 & 1 & 0.1759 \\ 2 & 1 & 1 & 1 & 0.4009 \\ 0.2753\end{array}\right.$

$\lambda \max =4.123$, C.R. $=0.046<0.1$, matrix is consistent.

Table 5. Weight summary and average weight for B3C

\begin{tabular}{|c|c|c|c|c|c|c|c|c|}
\hline & $\# 1$ & $\# 2$ & $\# 3$ & $\# 4$ & $\# 5$ & $\# 6$ & $\# 7$ & A.W. \\
\hline C9 & 0.1479 & 0.1250 & 0.2500 & 0.3000 & 0.1229 & 0.0746 & 0.3950 & 0.2022 \\
\hline C10 & 0.1759 & 0.1250 & 0.2500 & 0.1000 & 0.0550 & 0.1137 & 0.1317 & 0.1359 \\
\hline C11 & 0.4009 & 0.3750 & 0.2500 & 0.3000 & 0.4110 & 0.4318 & 0.1733 & 0.3346 \\
\hline C12 & 0.2753 & 0.3750 & 0.2500 & 0.3000 & 0.4110 & 0.3800 & 0.3001 & 0.3273 \\
\hline
\end{tabular}

For matrix $\mathrm{B} 4 \mathrm{C}$, the experts decided the sublayer weights under the students' experience, they compared interest level, acceptance of the content, comfort of the class.

\begin{tabular}{|c|c|c|c|c|}
\hline & B4 & C13 & C14 & C15 \\
\hline \multirow{3}{*}{$\mathrm{B} 4 \mathrm{C}=$} & C13 & 1 & 3 & 3 \\
\hline & C14 & $1 / 3$ & 1 & 3 \\
\hline & C15 & $1 / 3$ & $1 / 3$ & 1 \\
\hline
\end{tabular}

$\lambda \max =3.136$, C.R. $=0.117>0.1$, matrix is not consistent, the experts were asked to adjust their decision. They came up with this matrix afterwards,

$\mathrm{B} 4 \mathrm{C}=\begin{array}{ccccc}\mathrm{B} 4 & \mathrm{C} 13 & \mathrm{C} 14 & \mathrm{C} 15 & \text { weight } \\ \mathrm{C} 13 \\ \mathrm{C} 14 \\ \mathrm{C} 15\end{array}\left[\begin{array}{ccc}1 & 3 & 3 \\ 1 / 3 & 1 & 1 \\ 1 / 3 & 1 & 1\end{array}\right] \begin{aligned} & 0.6000 \\ & 0.2000 \\ & 0.2000\end{aligned}$

$\lambda \max =3.000$, C.R. $=0.000<0.1$, the matrix is consistent.

Table 6. Weight summary and average weight for B4C

\begin{tabular}{|c|c|c|c|c|c|c|c|c|}
\hline & $\# 1$ & $\# 2$ & $\# 3$ & $\# 4$ & $\# 5$ & $\# 6$ & $\# 7$ & A.W. \\
\hline C13 & 0.6000 & 0.2500 & 0.2897 & 0.4667 & 0.6491 & 0.0778 & 0.1692 & 0.3575 \\
\hline C14 & 0.2000 & 0.2500 & 0.6554 & 0.4667 & 0.2790 & 0.4869 & 0.4434 & 0.3973 \\
\hline C15 & 0.2000 & 0.5000 & 0.0549 & 0.0667 & 0.0719 & 0.4353 & 0.3874 & 0.2452 \\
\hline
\end{tabular}

For matrix $\mathrm{B} 5 \mathrm{C}$, the experts decided the sublayer weights under the teaching effect, they compared teaching evaluation scores, examination scores and goal achievement.

$\mathrm{B} 5 \mathrm{C}=\begin{gathered}\mathrm{B} 5 \\ \mathrm{C} 16 \\ \mathrm{C} 17 \\ \mathrm{C} 18\end{gathered}\left[\begin{array}{cccr}\mathrm{C} 16 & \mathrm{C} 17 & \mathrm{C} 18 & \text { weight } \\ 1 & 1 & 1 / 3 \\ 1 & 1 & 1 / 2 & 0.2098 \\ 3 & 2 & 1\end{array}\right] \begin{aligned} & 0.2402 \\ & 0.5499\end{aligned}$

$\lambda \max =3.018$, C.R. $=0.016<0.1$, the matrix is consistent.

Table 7. Weight summary and average weight for B5C

\begin{tabular}{|c|c|c|c|c|c|c|c|c|}
\hline & $\# 1$ & $\# 2$ & $\# 3$ & $\# 4$ & $\# 5$ & $\# 6$ & $\# 7$ & A.W. \\
\hline C16 & 0.2098 & 0.1571 & 0.4126 & 0.2922 & 0.0810 & 0.1047 & 0.0810 & 0.1912 \\
\hline C17 & 0.2402 & 0.2493 & 0.2599 & 0.0925 & 0.1884 & 0.2583 & 0.1884 & 0.2110 \\
\hline C18 & 0.5499 & 0.5936 & 0.3275 & 0.6153 & 0.7306 & 0.6370 & 0.7306 & 0.5978 \\
\hline
\end{tabular}

\subsection{Summarizing the Weights}

Then we summarize the relative weight of each indicator in the quality evaluation indicator system of the curriculum. Multiply the weight of the first-level index by the weight of the second-level index to obtain the global weight of the second-level index. Now the index weights at all levels are listed in Table 8. 
Table 8. The teaching quality evaluation index system of Ideological and political theory course

\begin{tabular}{|c|c|c|c|c|}
\hline \multicolumn{2}{|c|}{$\begin{array}{l}\text { First-level } \\
\text { index }\end{array}$} & \multicolumn{2}{|c|}{$\begin{array}{l}\text { Second-level } \\
\text { index }\end{array}$} & \multirow{2}{*}{$\begin{array}{c}\text { Overall } \\
\text { index }\end{array}$} \\
\hline \multirow{4}{*}{ B1 } & \multirow{4}{*}{0.1531} & $\mathrm{C} 1$ & 0.1502 & \\
\hline & & $\mathrm{C} 2$ & 0.2922 & 0.04474 \\
\hline & & $\mathrm{C} 3$ & 0.2247 & 0.03440 \\
\hline & & $\mathrm{C} 4$ & 0.3329 & 0.05097 \\
\hline \multirow{4}{*}{ B2 } & \multirow{4}{*}{0.3120} & $\mathrm{C} 5$ & 0.1857 & 0.05794 \\
\hline & & C6 & 0.2119 & 0.06611 \\
\hline & & $\mathrm{C} 7$ & 0.2061 & 0.06430 \\
\hline & & $\mathrm{C} 8$ & 0.3963 & 0.12365 \\
\hline \multirow{4}{*}{ B3 } & \multirow{4}{*}{0.2038} & C9 & 0.2022 & 0.04121 \\
\hline & & $\mathrm{C} 10$ & 0.1359 & 0.02770 \\
\hline & & C11 & 0.3346 & 0.06819 \\
\hline & & $\mathrm{C} 12$ & 0.3273 & 0.06670 \\
\hline \multirow{3}{*}{ B4 } & \multirow{3}{*}{0.1301} & C13 & 0.3575 & 0.04651 \\
\hline & & C14 & 0.3973 & 0.05169 \\
\hline & & $\mathrm{C} 15$ & 0.2452 & 0.03190 \\
\hline \multirow{3}{*}{ B5 } & \multirow{3}{*}{0.2010} & $\mathrm{C} 16$ & 0.1912 & 0.03843 \\
\hline & & $\mathrm{C} 17$ & 0.2110 & 0.04241 \\
\hline & & C18 & 0.5978 & 0.12016 \\
\hline
\end{tabular}

\section{CONCLUSION}

In short, based on the requirements of General Secretary $\mathrm{Xi}$ Jinping and the theory of curriculum evaluation, establish the concept of "element and line as the basis and the eight guidelines as the body", and integrate this concept into the ideological and political curriculum quality evaluation index system. AHP was used to determine the weights of 5 first-level indicators and 18 second-level indicators, establish a new era ideological and political course quality evaluation model, and thus provide teachers with a new direction for improving the quality of ideological and political teaching quality.

\section{ACKNOWLEDGMENT}

Funded Project: This article is a general project in teachers' special research for the ideological and political theory courses in colleges and universities (Ministry of Education of People's Republic of China, 2020), "Research on the evaluation index system and model construction of ideological and political theory courses in colleges and universities (20JDSZK079)", "Shaanxi Provincial Social Science Fund Annual Project (2021A002)", Shaanxi Provincial Educational Reform Project: The phased results of the research and practice of the ideological and political course teaching quality evaluation system based on the requirements of the "six requirements and the eight unifications"(21BZ039).

\section{REFERENCES}

[1] Leisheng Zhang, Important follow-up in the teaching of ideological and political theory in the new era[J] (In Chinese). Research on Marxist Theoretical Subjects. 2019 (2) 14-22.

[2] Shuyin Wang, Ideological and political teachers in colleges and universities "politics must be strong"[J] (In Chinese). China Higher Education Social Sciences.2019 (3) $11-15$.

[3] Wenjing Sun, etc., College Ideological and Political Teacher Classroom Based on Student Evaluation[J] (In Chinese). School Party Building and Ideological Education. 2020 (6).

[4] Yaocan Zhang, Research on the Education and Teaching Quality Monitoring System of Ideological and Political Theory Courses in Colleges and Universities (In Chinese). Economic Science Press, May 2014.

[5] Shubai Xu, Principle of analytic hierarchy process (In Chinese). Tianjin: Tianjin University press,1988.

[6] E.H.Forman, Random indices for Incomplete Pairwise Comparison Matrices. European Journal of Operational Research 48, (1990) 153-155 DOI: https://doi.org/10.1016/0377-2217(90)90072-J 